\title{
Associations of Health Literacy with Blood Pressure and Dietary Salt Intake among Adults: A Systematic Review
}

\author{
Darwish Mohd Isa ${ }^{1}$, Suzana Shahar ${ }^{2}$, Feng J. He ${ }^{3} D$ and Hazreen Abdul Majid ${ }^{1,4, *}$ \\ 1 Centre for Population Health, Department of Social and Preventive Medicine, Faculty of Medicine, \\ University of Malaya, Kuala Lumpur 50603, Malaysia; darwish@um.edu.my \\ 2 Faculty of Health Sciences, National University of Malaysia, Kuala Lumpur 50300, Malaysia; \\ suzana.shahar@ukm.edu.my \\ 3 Wolfson Institute of Preventive Medicine, Barts and The London School of Medicine and Dentistry, \\ Queen Mary University of London, London E1 2AD, UK; f.he@qmul.ac.uk \\ 4 Faculty of Public Health, Universitas Airlangga, Jawa Timur 60115, Indonesia \\ * Correspondence: hazreen.abdulmajid@gmail.com; Tel.: +60-3-7967-4757
}

Citation: Mohd Isa, D.; Shahar, S.; He, F.J.; Majid, H.A. Associations of Health Literacy with Blood Pressure and Dietary Salt Intake among Adults: A Systematic Review. Nutrients 2021, 13, 4534. https:// doi.org/10.3390/nu13124534

Academic Editor: Jaakko Tuomilehto

Received: 7 October 2021

Accepted: 14 December 2021

Published: 17 December 2021

Publisher's Note: MDPI stays neutral with regard to jurisdictional claims in published maps and institutional affiliations.

Copyright: (c) 2021 by the authors. Licensee MDPI, Basel, Switzerland. This article is an open access article distributed under the terms and conditions of the Creative Commons Attribution (CC BY) license (https:// creativecommons.org/licenses/by/ $4.0 /)$.

\begin{abstract}
Health literacy has been recognized as a significant social determinant of health, defined as the ability to access, understand, appraise, and apply health-related information across healthcare, disease prevention, and health promotion. This systematic review aims to understand the relationship between health literacy, blood pressure, and dietary salt intake. A web-based search of PubMed, Web of Science, CINAHL, ProQuest, Scopus, Cochrane Library, and Prospero was performed using specified search/MESH terms and keywords. Two reviewers independently performed the data extraction and analysis, cross-checked, reviewed, and resolved any discrepancies by the third reviewer. Twenty out of twenty-two studies met the inclusion criteria and were rated as good quality papers and used in the final analysis. Higher health literacy had shown to have better blood pressure or hypertension knowledge. However, the relationship between health literacy with dietary salt intake has shown mixed and inconsistent findings. Studies looking into the main four domains of health literacy are still limited. More research exploring the links between health literacy, blood pressure, and dietary salt intake in the community is warranted. Using appropriate and consistent health literacy tools to evaluate the effectiveness of salt reduction as health promotion programs is required.
\end{abstract}

Keywords: health literacy; blood pressure; hypertension; salt intake; adult; systematic review

\section{Introduction}

Cardiovascular diseases (CVDs) remain one of the worldwide leading causes of death, leading to the deaths of 17.9 million people annually [1]. Heart attacks and strokes are responsible for $80 \%$ of CVD deaths, with one-third of these deaths happening in those younger than 70 years old highlighted in the World Health Organisation (WHO) report [2]. However, the relative risk from CVD deaths can be significantly reduced by managing blood pressure. [3]. Looking at the current trend, it is estimated that approximately 1.5 billion people will have hypertension by 2025 [4]. Similarly, CVDs remain the major cause of mortality in Malaysia, according to the Departments of Statistics Malaysia, 2020 [5]. Three in ten or 6.4 million people in Malaysia were reported to have hypertension [6]. One of the global goals for reducing non-communicable diseases (NCDs) is to reduce hypertension prevalence to $25 \%$ by 2025 , against a 2010 baseline.

Excessive salt intake is the main contributing factor towards hypertension, with strokes accounting for $62 \%$ and coronary heart disease for $49 \%$ [7]. According to the WHO, the most cost-effective public health strategy to lower NCDs includes salt reduction [8]. In addition, it is one of the top three priorities for addressing the worldwide NCD crisis. Blood pressure can be lowered by reducing salt consumption among hypertensive and normotensive people, and it works in conjunction with antihypertensive medications [9]. 
Evidence has shown that the risk of CVD and death can be minimized by lowering salt consumption.

Between 2003 and 2011, population salt intake had reduced by 15\% with the implementation of the United Kingdom's salt reduction policy, where 85 product categories were set to lower salt content via independent monitoring. It appeared that there was a decrease in CVD mortality [10]. Following the UK's lead, 96 countries currently have some salt reduction strategy in place [11]. Despite WHO recommendations of dietary salt intake below $5 \mathrm{~g}$ per day, salt intake remains high globally [12]. In Malaysia, outside foods are the well-known major contributor to high salt intake among the population. However, there is barely any movement or efforts made to address the issue [13].

Looking at the current trends, health literacy research is scarce. Health literacy is defined as the ability to access, understand, appraise, and apply health information in everyday life to make judgments and decisions about healthcare, disease prevention, and health promotion to maintain or improve one's quality of life over time [14]. The concept of health literacy has risen in importance over the last two decades as a result of its numerous benefits to individuals, public health, and the healthcare system as a whole [14-18] and was even considered as one of the crucial determinants of health. Many studies have clearly shown the adverse health outcomes for health illiterate people, such as health issues, inefficient use of healthcare, increasing barriers to care, and early mortality [19]. In addition, an earlier systematic review has also found that limited health literacy hypertensive patients tend to have poor hypertension knowledge [20]. However, it is not clear about the general population level of health literacy regarding hypertension and salt intake itself. Available evidence suggested inconsistent and mixed findings between health literacy with blood pressure control and dietary salt intake among adults.

One of the most cost-effective strategies to fight NCD is to improve health literacy $[19,21]$. However, research on health literacy towards blood pressure control, salt intake, and other topics has shown mixed and contradictory results. Hence, the focus of this research is to learn more about the relationships between health literacy and dietary salt intake and blood pressure in adults.

\section{Materials and Methods}

\subsection{Eligibility Criteria}

A systematic review was conducted using the Preferred Reporting Items for Systematic Reviews and Meta-Analyses reporting criteria (PRISMA 2020) and was designed according to PICOS (Participant, Intervention, Comparison, Outcomes, and Study Design) criteria (Table 1). The review protocol (PROSPERO Registration number. CRD42021243596) has been registered with the International Prospective Register of Systematic Reviews.

Table 1. The PICOS criteria used to construct the systematic review.

\begin{tabular}{cr}
\hline Criteria & Description \\
\hline Participants & $\begin{array}{c}\text { Adults aged } \geq 18 \text { years, including those with the hypertensive condition. Animal } \\
\text { studies and individuals with other specific diseases were excluded }\end{array}$ \\
\hline Intervention/Exposure & Health literacy \\
\hline Comparison & $\begin{array}{c}\text { High vs low health literacy in relation to the outcomes (blood pressure and dietary } \\
\text { salt intake) either by mean scores, quartiles, or cut-off values such as limited, } \\
\text { adequate, marginal, and excellent health literacy }\end{array}$ \\
\hline Outcomes & Dietary salt intake and blood pressure using validated measurements and protocol \\
\hline Study Design & Randomised controlled trial (RCT), non-RCT, cohort, and cross-sectional studies \\
\hline
\end{tabular}

A systematic literature search was conducted to identify studies that reported on the relationships between health literacy and blood pressure and dietary salt intake in people over the age of 18 years. It focused on the association between health literacy with dietary 
salt and blood pressure, using quantitatively validated instruments for health literacy and dietary salt and blood pressure. For intervention studies, only explicit interventions aiming at lowering blood pressure and dietary salt were considered. Studies that did not use any health literacy tools did not report any outcome of interest, were not published in English or Mandarin, were rated as poor or fair quality, or involved patients with specific conditions were all excluded.

\subsection{Information Sources}

A web-based search of PubMed, Web of Science, CINAHL, ProQuest, Scopus, Cochrane Library, and Prospero was performed. Databases search was supplemented with grey literature, internet searches (e.g., Google Scholar), reference lists of studies included in the systematic review, and manual search. The last search was run on 1 March 2021.

\subsection{Search Strategy}

The search was limited to English and Mandarin literature, published from January 2010 to March 2021, and will be re-run prior to the final analysis. Keywords and MESH terms, "health literacy" or "literacy" OR "numeracy" with "salt" or "salty" or "sodium" or "hypertension" or "blood pressure" were utilized and combined with the search using Boolean terms such as "AND" and "OR" (Table 2).

Table 2. Terms used for search strategy.

\begin{tabular}{|c|c|c|}
\hline Concept 1 & & Concept 2 \\
\hline $\begin{array}{c}\text { Health Literacy OR } \\
\text { Literacy OR } \\
\text { Numeracy }\end{array}$ & AND & $\begin{array}{c}\text { Salt OR } \\
\text { Salty OR } \\
\text { Sodium } \\
\text { Blood Pressure OR } \\
\text { Hypertension }\end{array}$ \\
\hline
\end{tabular}

\subsection{Selection Process}

Articles were chosen in three stages: selection based on titles, followed by abstract consideration, and assessing the full text. Bibliographic information such as author, publication year, title, and journal, study design, setting, country, inclusion and exclusion criteria, subject recruitment, age, gender, and the study's duration and dates were all acquired. Any mandarin language papers were translated by one of the reviewers.

\subsection{Data Collection Process}

The data gathered were then exported to Microsoft Excel from Mendeley, a reference manager software, and full texts. Two reviewers independently performed the data extraction and analysis, cross-checked, and reviewed and resolved any discrepancies by the third reviewer.

\subsection{Data Items}

To meet the objective of the review (i.e., understanding the associations between health literacy with blood pressure and dietary salt intake), tools utilized for assessing subjects' health literacy, the appropriateness of blood pressure and salt intake measurement, and the outcomes of the associations were included. Other variables such as sociodemographic characteristics, knowledge, attitude, practice (KAP), and nutritional status were also extracted. The results of the measurements and the statistical methods used to assess the associations between them were then recorded along with the related conclusion and recommendations. All outcomes compatible with the outcome domain were sought in each study. The original authors of the studies were contacted when more information about the study outcomes or other details were needed. 


\subsection{Study Risk of Bias Assessment}

Observational studies were assessed using the Newcastle-Ottawa quality assessment scale adapted for cross-sectional and cohort studies, measuring the selection, comparability, and outcomes. For interventions studies, random sequence generation, allocation concealment, selective reporting, other bias, blinding of participants and personnel, blinding of outcome assessment, and missing outcome data were all assessed using Cochrane's collaboration tool. Quality scores were rated as "Good", "Fair" or "Poor" quality. Each study's risk of bias was independently assessed by two reviewers, and any disagreements were discussed with the third author. The bias assessment was reported in the tabulation.

\subsection{Outcome Measures}

Binary and continuous outcomes were gathered, and effective measures such as mean, mean difference, and odds ratios of the outcomes were used to synthesize and present results. The review also included other calculations/statistics, such as quartiles.

\subsection{Synthesis Methods}

The results were performed in tabulation and visual display of methods. A narrative synthesis of findings detailing the association between health literacy with blood pressure and dietary salt intake was performed.

\section{Results}

\subsection{Study Selection}

After eliminating duplicates from the databases, 1960 articles were identified. A total of 39 full texts were analyzed after the title and abstract screening. Twenty-two studies out of 39 met the requirements for inclusion, while 17 were excluded as they did not fit the criteria, did not report any outcome of interest, did not use any health literacy instrument, and involved patients with specific diseases other than hypertension. After quality assessment, two were removed as they were poor or fair quality papers [22,23], and the remaining 20 studies were included for synthesis. The PRISMA flow diagram of the literature search is shown in Figure 1.

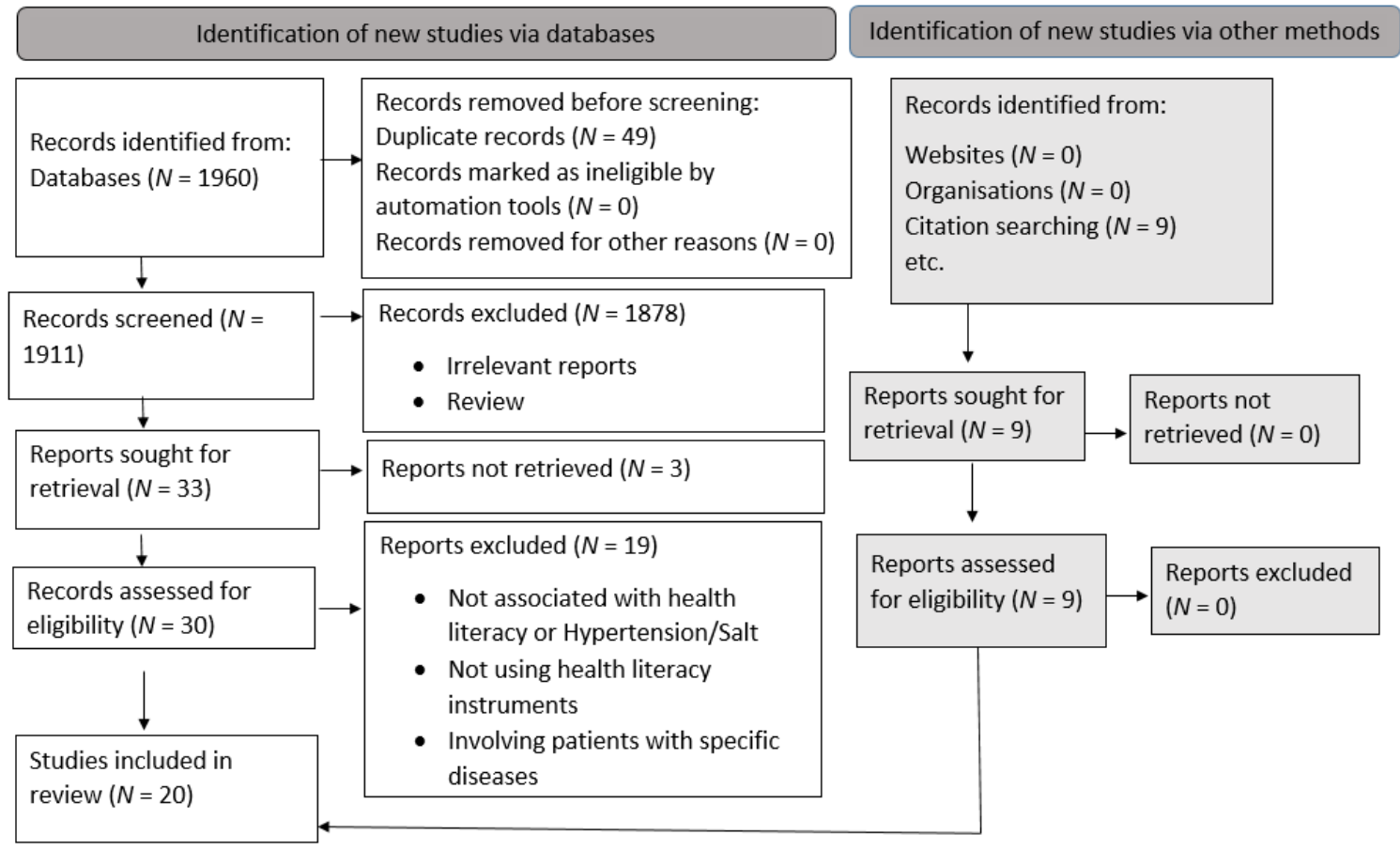

Figure 1. Flow diagram for study selection. 


\subsection{Study Characteristics}

There were 18 cross-sectional studies, one cohort study, and one RCT among the 20 papers included. The studies were conducted in United States $(N=7)$, Brazil $(N=2)$, Turkey $(N=2)$, Switzerland $(N=1)$, China $(N=1)$, Japan $(N=2)$, Iran $(N=2)$, Singapore $(N=1)$, Thailand $(N=1)$, and Cambodia $(N=1)$. All of the studies illustrate the relationship between health literacy with either blood pressure control or salt intake. Seventeen papers measured the associations between health literacy and blood pressure control, while three papers measured salt intake. Participants in studies include adults aged 18 years and above and the elderly, mostly with hypertensive conditions $(N=17)$. All studies used validated health literacy instruments though they varied considerably. Health literacy was most commonly measured by using Rapid Estimate of Adult Literacy in Medicine (REALM), a short version of the Test of Functional Health Literacy in Adults (STOFHLA), Newest Vital Sign (NVS), and Brief Health Literacy Screening (BHLS). The majority of studies or tools used to assess health literacy did not include all four main domains of health literacy; the ability to access, understand, appraise and apply health information. Out of 20 studies included, most studies assessed one's ability to understand $(n=15)$, followed by appraise $(N=9)$, and apply $(N=9)$ health information, however very limited is known about the ability to access $(N=6)$ and the overall four domains of health literacy $(N=5)$. Most studies only assessed three health literacy domains at most.

For the outcome measurement, most studies used blood pressure measurement to assess blood pressure control. However, methods of salt measurement were diverse, including $24 \mathrm{~h}$ urine sodium (gold standard) and a twelve-item scale that assessed nutrition practices based on a low salt, DASH diet, and HL-SR (Health Literacy on Sodium Restriction). Table 3 lists the general characteristics of each study as well as the findings.

\subsection{Quality Assessment}

Of the 22 papers included initially, 20 are graded as good, the other two as fair and poor quality, hence were excluded from synthesis [22,23]. Details summary of quality appraisal is illustrated in Tables 4-6. for cross-sectional studies, cohort studies, and randomized trials, respectively. 
Table 3. General characteristics of studies included in the final analysis.

\begin{tabular}{|c|c|c|c|c|c|}
\hline Author (Year) & Design & Instrument & Quality Score & Study Sample & $\begin{array}{c}\text { Outcomes (Blood } \\
\text { Pressure/Knowledge/Salt } \\
\text { Intake) }\end{array}$ \\
\hline Delavar et al., 2020 [24] & RCT (January-March 2018) & $\begin{array}{l}\text { Health Literacy for Iranian } \\
\text { Adults (HELIA) }\end{array}$ & Good & $\begin{array}{l}\text { Through block randomization, } \\
118 \text { older adults with } \\
\text { uncontrolled hypertension were } \\
\text { allocated to a control or } \\
\text { intervention group at random. } \\
\text { Age more than } 60 \text { years old. }\end{array}$ & $\begin{array}{l}\text { Blood pressure: After Health } \\
\text { Literacy-tailored intervention, } \\
\text { blood pressure among the } \\
\text { intervention group is improved; } \\
\text { nevertheless, there was no } \\
\text { evident difference between the } \\
\text { groups }(p>0.05) \text {. }\end{array}$ \\
\hline Gaffari-fam et al., 2020 [25] & Cross-sectional & HELIA & Good & $\begin{array}{c}210 \text { hypertensive patients in Iran. } \\
\text { Age more than } 30 \text { years (Mean } \\
\text { age was } 56.7 \text { years) }\end{array}$ & $\begin{array}{l}\text { Blood pressure: The health } \\
\text { literacy dimensions contributed } \\
\text { to a significant increase of } 4.7 \% \\
\text { for the variance in high blood } \\
\text { pressure. }\end{array}$ \\
\hline Costa et al., 2019 [26] & Cross-sectional & $\begin{array}{c}\text { The Short Assessment of } \\
\text { Health Literacy for } \\
\text { Portuguese-speaking Adults } \\
\text { (18 items) } \\
\text { SAHLPA-18 }\end{array}$ & Good & $\begin{array}{l}392 \text { hypertensive elderly patients. } \\
\text { More than } 60 \text { years. }\end{array}$ & $\begin{array}{l}\text { Blood pressure: Inadequate } \\
\text { (high) blood pressure was linked } \\
\text { to the following factor: } \\
\text { inadequate functional health } \\
\text { literacy. }\end{array}$ \\
\hline Borges et al., 2019 [27] & Cross-sectional & $\begin{array}{l}\text { Short Test of Functional } \\
\text { Health Literacy in Adults } \\
\text { (S-TOFHLA) }\end{array}$ & Good & $\begin{array}{l}357 \text { adults from basic health units } \\
\text { in Brazil. Aged between } 18 \text { to } \\
39 \text { years }\end{array}$ & $\begin{array}{l}\text { Blood pressure: There was a } \\
\text { statistically significant decrease } \\
\text { in associations evaluated } \\
(p<0.05) \text { when it came to } \\
\text { hypertension and participants' } \\
\text { health literacy level. }\end{array}$ \\
\hline Study, Year (References) & Design & Instrument & Quality Score & Study Sample & $\begin{array}{c}\text { Outcomes (Blood } \\
\text { Pressure/Knowledge/Salt } \\
\text { Intake) }\end{array}$ \\
\hline Selcuk et al., 2018 [28] & Cross-sectional & $\begin{array}{c}\text { European Health Literacy } \\
\text { Survey Questionnaire } \\
\text { (HLS-EU-Q) }\end{array}$ & Good & $\begin{array}{l}556 \text { hypertensive patients in } \\
\text { Turkey. Aged } 18 \text { years and above. } \\
\text { Mean age was } \\
55.74 \pm 13.69 \text { years (range } 18-88 \text { ) }\end{array}$ & $\begin{array}{c}\text { Blood pressure: According to } \\
\text { multivariate logistic regression } \\
\text { analysis, health illiterate patients } \\
\text { had higher uncontrolled blood } \\
\text { pressure (OR: } 2.06,95 \% \text { CI: } \\
\text { 1.34-2.94). }\end{array}$ \\
\hline
\end{tabular}


Table 3. Cont.

\# Halladay et al., 2017 [22]

Cohort

STOFHLA

Fair

93 patients with uncontrolled

hypertension in rural primary

care, US. The mean age was 57

$(\min =20, \max =92)$ years
Blood pressure: There were

statistically significant reductions

in mean Systolic Blood Pressure

(SBP) in both the low and high

health literacy groups (6.6 and

$5.3 \mathrm{mmHg}$, respectively) after a

year, however, there was no

significant difference between the groups $(\Delta 1.3 \mathrm{mmHg}, p=0.067)$.

The low and high health literacy

groups both reported lower

blood pressure in 2 years by 8.1 and $4.6 \mathrm{~mm} \mathrm{Hg}$, respectively,

$$
\text { with no significant }
$$

between-group difference

$(\Delta 3.5 \mathrm{~mm} \mathrm{Hg}, p=0.25)$.

\section{Outcomes (Blood}

\section{Pressure/Knowledge/Salt} Intake)

Blood pressure: Low health

literacy indicates high SBP. The

rate of hypertension control

increased as the CHLSH score increased $(p<0.001)$. The

findings show that for

tensive patients in for hypertension (CHLSH)

Poor
China. The age range of

participants was $31-88$ years. three-quarters of the year,

patients in the high literacy

group have better SBP

management than those in the

low literacy group. 
Table 3. Cont.

Hu et al., 2017 [29]

Cross-sectional

Health Literacy Scale for

Hypertension
Good

596 hypertensive patients in China

Blood pressure: Blood pressure control was linked to total health

literacy $(z=2.493, p=0.013)$

ability to comprehend pictures

$(z=3.187, p=0.001)$, and

accessing health-related

information $(z=3.274, p=0.001)$.

Blood pressure: Health literacy

was shown to be insignificant

500 volunteer teachers aged

Newest Vital Sign Scale and

Blood Pressure Concept Test

Good

35-49. The mean age of the study

(adapted from REALM)

group

the hypertensive subjects,

$$
48.35 \pm 7.53 \text {. }
$$

when it came to hypertension awareness and

control Knowledge: Those with

hypertension who were aware of

the disease had a higher health

literacy level than those who

were not $(p>0.05)$

\section{Outcomes (Blood}

Pressure/Knowledge/Salt Intake)

\begin{tabular}{|c|c|c|c|c|c|}
\hline Study, Year (References) & Design & Instrument & Quality Score & Study Sample & $\begin{array}{c}\text { Pressure/Knowledge/Salt } \\
\text { Intake) }\end{array}$ \\
\hline Hall et al., 2016 [31] & Cross-sectional & $\begin{array}{l}\text { SAHLSA (Short Assessment } \\
\text { of Health Literacy for } \\
\text { Spanish-Speaking Adults) }\end{array}$ & Good & $\begin{array}{l}45 \text { Latino Migrant and Seasonal } \\
\text { Farmworkers. Ages ranged from } \\
29 \text { to } 60\end{array}$ & $\begin{array}{l}\text { Blood pressure: Higher levels of } \\
\text { acculturation and health literacy } \\
\text { were linked to improved blood } \\
\text { pressure control }(p=0.01) .\end{array}$ \\
\hline Wannasirikul et al., 2016 [32] & Cross-sectional & $\begin{array}{l}\text { Adopted from Ishikawa et al. } \\
\qquad(2008)\end{array}$ & Good & $\begin{array}{l}600 \text { aged } 60 \text { to } 70 \text { years with a } \\
\text { mean age of } 65.3 \text { years for } \\
\text { hypertensive patients in Primary } \\
\text { Health Care Centres in Thailand }\end{array}$ & $\begin{array}{l}\text { Blood pressure: Blood pressure is } \\
\text { strongly linked with health } \\
\text { literacy }(\beta=-0.14, p<0.05) \text {. }\end{array}$ \\
\hline Glashen, 2015 [33] & Cross-sectional & STOFHLA & Good & $\begin{array}{l}136 \text { hypertensive Latino adults in } \\
\text { the US aged } 18 \text { to } 49 \text { years }\end{array}$ & $\begin{array}{l}\text { Blood pressure: Health literacy } \\
\text { and hypertension association } \\
\text { were not statistically significant } \\
\quad\left(\chi^{2}(1)=0.811, p=0.368\right)\end{array}$ \\
\hline
\end{tabular}


Table 3. Cont.

\begin{tabular}{|c|c|c|c|c|c|}
\hline McNaughton et al., 2014 [34] & $\begin{array}{l}\text { Cross-sectional evaluation } \\
\text { between } 1 \text { November } 2010 \\
\text { and } 30 \text { April } 2012\end{array}$ & $\begin{array}{l}\text { Brief Health Literacy Screen } \\
\text { (BHLS) }\end{array}$ & Good & $\begin{array}{c}46,263 \text { hospitalizations were } \\
\text { available for analysis. Aged } \\
18 \text { years or older }\end{array}$ & $\begin{array}{l}\text { Blood pressure: Low health } \\
\text { literacy indicates extreme high } \\
\text { blood pressure (aOR 1.08, } \\
95 \% \text { confidence CI 1.01, 1.16) and } \\
\text { high blood pressure in people } \\
\text { who had never been diagnosed } \\
\text { with hypertension (OR 1.09, } \\
\text { 95\% CI 1.02, 1.16). Such } \\
\text { associations were not found } \\
\text { among patients with low health } \\
\text { literacy and diagnosed } \\
\text { hypertension. }\end{array}$ \\
\hline McNaughton et al., 2014 [35] & Cross-sectional & $\begin{array}{l}\text { The Rapid Estimate of Adult } \\
\text { Literacy in Medicine } \\
\text { (REALM) }\end{array}$ & Good & $\begin{array}{l}423 \text { urban hypertensive patients } \\
\text { with coronary disease in the US }\end{array}$ & $\begin{array}{c}\text { Blood pressure: Limited health } \\
\text { literacy indicates uncontrolled } \\
\text { blood pressure (OR 1.75, 95\% CI } \\
1.06-2.87) .\end{array}$ \\
\hline Study, Year (References) & Design & Instrument & Quality Score & Study Sample & $\begin{array}{c}\text { Outcomes (Blood } \\
\text { Pressure/Knowledge/Salt } \\
\text { Intake) }\end{array}$ \\
\hline Ko et al., 2013 [36] & Cross-sectional & STOFHLA Singapore & Good & $\begin{array}{l}306 \text { hypertensive patients in the } \\
\text { primary clinic in Singapore }\end{array}$ & $\begin{array}{l}\text { Blood pressure: The degree of } \\
\text { health literacy did not affect } \\
\text { achieving the target blood } \\
\text { pressure }(p=0.71) \text {. } \\
\text { Knowledge: Higher health } \\
\text { literacy level indicates higher } \\
\text { hypertension knowledge scores } \\
(p<0.001) .\end{array}$ \\
\hline Willens et al., 2013 [37] & Cross-sectional & BHLS & Good & $\begin{array}{l}10644 \text { hypertensive patients aged } \\
\text { more than } 18 \text { years }\end{array}$ & $\begin{array}{l}\text { Blood pressure: Health literate } \\
\text { patients had a slightly lower } \\
\text { odds of having their } \\
\text { hypertension under control. }\end{array}$ \\
\hline Aboumatar et al., 2013 [38] & Cross-sectional & REALM & Good & $\begin{array}{c}275 \text { hypertensive patients in the } \\
\text { US }\end{array}$ & $\begin{array}{l}\text { Blood pressure: Patients with } \\
\text { limited literacy reported poorer } \\
\text { blood pressure management at } \\
\text { the baseline. }\end{array}$ \\
\hline
\end{tabular}


Table 3. Cont.

\begin{tabular}{|c|c|c|c|c|c|}
\hline Lenahan et al., 2013 [39] & Cross-sectional & TOFHLA & Good & $\begin{array}{l}215 \text { hypertensive patients in the } \\
\text { United States with an average } \\
\text { age of } 60 \text { years old } \\
\text { (SD }=8.0 \text { years) }\end{array}$ & $\begin{array}{l}\text { Blood pressure: Uncontrolled } \\
\text { blood pressure }(p=0.03) \text { and } \\
\text { medication identification } \\
(p=0.001) \text { were both associated } \\
\text { with health literacy. }\end{array}$ \\
\hline Shibuya et al., 2011 [40] & Cross-sectional & $\begin{array}{c}\text { Chinese Health Literacy } \\
\text { (CHL) }\end{array}$ & Good & $\begin{array}{l}320 \text { Middle-aged participants in } \\
\text { an urban clinic, Japan ( } 53 \text { to } \\
57 \text { years) with an average age of } \\
54.4 \text { years old }\end{array}$ & $\begin{array}{l}\text { Blood pressure: Limited health } \\
\text { literacy and hypertension } \\
\text { knowledge indicate poor health } \\
\text { and raised blood pressure }\end{array}$ \\
\hline Study, Year (References) & Design & Instrument & Quality Score & Study Sample & $\begin{array}{c}\text { Outcomes (Blood } \\
\text { Pressure/Knowledge/ Salt } \\
\text { Intake) }\end{array}$ \\
\hline $\begin{array}{c}\text { Suon and Ruaisungnoen, } \\
2019 \text { [41] }\end{array}$ & Cross-sectional & $\begin{array}{l}\text { Health Literacy Sodium } \\
\text { Restriction (HL-SR) }\end{array}$ & Good & $\begin{array}{l}317 \text { hypertensive patients in } \\
\text { Cambodia. Age }(21-72 \text { years old }) \\
\text { with average age of } 54 \text { years } \\
(\mathrm{SD}=8.95)\end{array}$ & $\begin{array}{c}\text { Salt Intake: Literacy skills } \\
(\beta=0.125, p=0.019), \text { knowledge } \\
\text { of hypertension and sodium } \\
\text { restriction }(\beta=0.266, p<0.001), \\
\text { and health professional } \\
\text { communication }(\beta=0.359, \\
p<0.001) \text { were reported to be } \\
\text { strongly associated to Health } \\
\text { Literacy-Sodium Restriction. } \\
\text { Salt Intake: The health literacy }\end{array}$ \\
\hline Luta et al., 2018 [3] & Cross-sectional & $\begin{array}{c}\text { European Health Literacy } \\
\text { Survey Questionnaire 47-item } \\
\text { (HLS-EU-Q47) }\end{array}$ & Good & $\begin{array}{l}141 \text { workplace population in } \\
\text { Switzerland. Ages of } 15 \text { and } 65\end{array}$ & $\begin{array}{l}\text { index and food literacy score did } \\
\text { not have a significant } \\
\text { relationship with salt intake ( } 24 \mathrm{~h} \\
\text { urine), however, the awareness } \\
\text { variable "salt content impacts } \\
\text { food/menu choice" did. }\end{array}$ \\
\hline Hutchison et al., 2014 [42] & Cross-sectional & Newest Vital Sign & Good & $\begin{array}{l}250 \text { hypertensive patients in } \\
\text { primary clinical care in the US. } \\
\text { Age from } 30 \text { to } 85 \text { years (with an } \\
\text { average age of } 55 \text { years). }\end{array}$ & $\begin{array}{l}\text { Salt Intake: Adequate health } \\
\text { literacy indicates a higher chance } \\
\text { of adhering to the low salt plus } \\
\text { diet (OR }=1.18,95 \% \mathrm{CI} \text { : } \\
0.50-2.79) \text { than those with limited } \\
\text { health literacy, but the results } \\
\text { were not significant. }\end{array}$ \\
\hline
\end{tabular}


Table 4. Summary of Quality Assessment of the included studies using the Newcastle-Ottawa Quality Assessment Scale (adapted for cross-sectional studies).

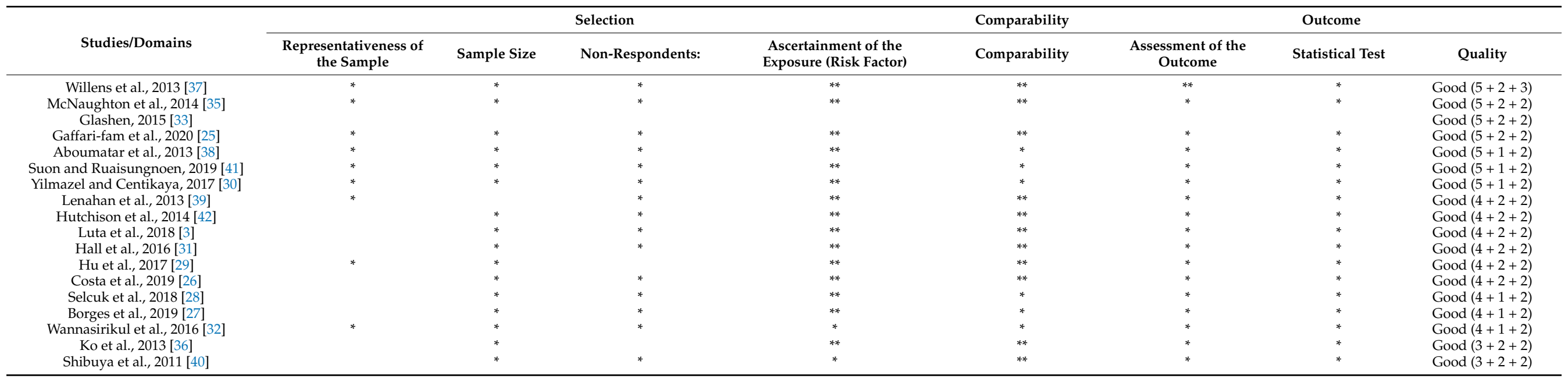

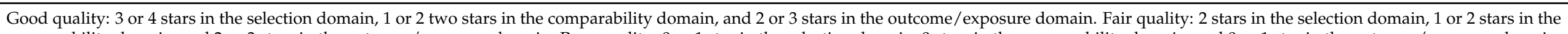

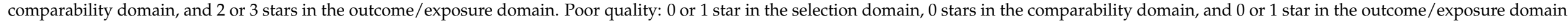

Table 5. Summary of quality assessment of the included studies using Newcastle-Ottawa Quality Assessment Scale (Cohort Studies).

\begin{tabular}{|c|c|c|c|c|c|c|c|c|c|}
\hline \multirow[b]{2}{*}{ Studies/Domains } & \multicolumn{4}{|c|}{ Selection } & \multirow{2}{*}{$\begin{array}{l}\text { Comparability } \\
\text { Comparability }\end{array}$} & \multicolumn{4}{|c|}{ Outcome } \\
\hline & $\begin{array}{l}\text { Representativeness } \\
\text { of the Exposed } \\
\text { Cohort }\end{array}$ & $\begin{array}{l}\text { Selection of the } \\
\text { Non-Exposed } \\
\text { Cohort }\end{array}$ & $\begin{array}{l}\text { Ascertainment of } \\
\text { Exposure }\end{array}$ & $\begin{array}{l}\text { Demonstration that } \\
\text { Outcome of Interest was } \\
\text { not Present at the Start } \\
\text { of the Study }\end{array}$ & & $\begin{array}{l}\text { Assessment of } \\
\text { Outcome }\end{array}$ & $\begin{array}{l}\text { Was Follow-Up } \\
\text { Long Enough for } \\
\text { Outcomes to Occur }\end{array}$ & $\begin{array}{l}\text { Adequacy of } \\
\text { Follow-Up of } \\
\text { Cohorts }\end{array}$ & Quality \\
\hline \# Halladay et al., 2017 [22] & & * & & * & ** & * & * & * & $\begin{array}{c}\text { Fair } \\
(2+2+3)\end{array}$ \\
\hline \# Shi et al., 2017 [23] & * & * & & * & $* *$ & & * & & $\begin{array}{c}\text { Poor } \\
(3+2+1)\end{array}$ \\
\hline
\end{tabular}

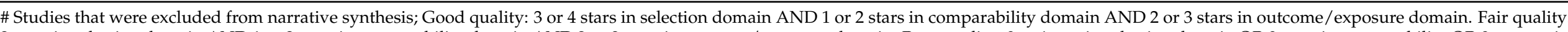

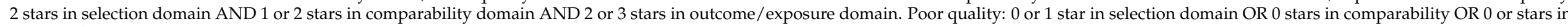
outcome/exposure domain. 
Table 6. Summary of quality assessment of the included studies using Cochrane's collaboration tool for assessing the risk of bias in randomized trials.

\begin{tabular}{|c|c|c|c|c|c|c|c|c|}
\hline & $\begin{array}{c}\text { Random } \\
\text { Sequence } \\
\text { Generation }\end{array}$ & $\begin{array}{c}\text { Allocation } \\
\text { Concealment }\end{array}$ & $\begin{array}{c}\text { Blinding of } \\
\text { Participant and } \\
\text { Personnel }\end{array}$ & $\begin{array}{l}\text { Blinding of } \\
\text { Outcome } \\
\text { Assessment }\end{array}$ & $\begin{array}{l}\text { Incomplete } \\
\text { Outcome Data }\end{array}$ & $\begin{array}{l}\text { Selective } \\
\text { Reporting }\end{array}$ & $\begin{array}{c}\text { Other Bias Due to } \\
\text { Problems Not Covered } \\
\text { Elsewhere }\end{array}$ & Quality \\
\hline Delavar et al., 2020 [24] & Low risk & Low risk & Low risk & Unclear risk & Low risk & Low risk & Low risk & Good \\
\hline
\end{tabular}

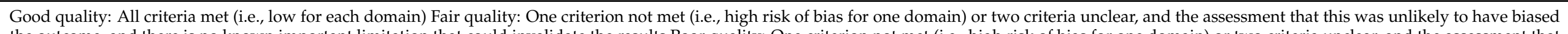

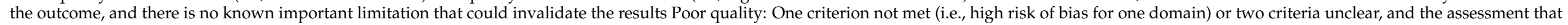
this was likely to have biased the outcome, and there are important limitations that could invalidate the results Poor quality: Two or more criteria listed as high or unclear risk of bias. 


\subsection{Health Literacy Status}

Health literacy status varied. This could be due to the participants' diverse backgrounds, as well as differences in the types of tools and reporting methods used. Most studies categorized health literacy into two or more groups; limited and adequate; limited, marginal, adequate; problematic, inadequate, sufficient, excellent. Four studies presented health literacy status as mean and standard deviation $[25,30,31,41]$, while one study reported health literacy using quartile [29]. Most of the studies determined the associations between health literacy and outcomes using a categorical approach by defining hypertension and health literacy levels, and some use health literacy index [3] quartiles and mean scores against systolic and diastolic blood pressure [37,40], hypertension, or salt intake levels. One study compared the proportions of the individuals who controlled systolic and diastolic blood pressure to the target between groups after intervention [24].

\subsection{Health Literacy and Outcomes}

Table 7 summarises the associations between health literacy and the outcomes of 20 papers included. The outcomes were grouped into two categories: Blood Pressure and Salt. Blood pressure control $(N=17)$ was the most commonly done, followed by salt $(N=3)$. One study [3] discussed two salt outcomes: salt intake ( $24 \mathrm{~h}$ urine) and awareness. Two studies $[30,36]$ out of 20 papers included hypertension or blood pressure knowledge as an outcome and were included in the table, making a total of 23 outcomes.

Table 7. Health literacy and outcomes: summary of findings.

\begin{tabular}{|c|c|c|c|c|c|}
\hline Category & Outcome & $\begin{array}{l}\text { Design (Total Number } \\
\text { of Studies by Design) }\end{array}$ & Positive Results $(p<0.05)$ & $\begin{array}{c}\text { Negative } \\
\text { Results } \\
(p<0.05)\end{array}$ & $\begin{array}{l}\text { Non-Significant } \\
\text { Results }(p>0.05)\end{array}$ \\
\hline \multirow{4}{*}{ Blood pressure } & \multirow{3}{*}{ Blood pressure control } & Cross-sectional $(N=15)$ & 11 & 1 & 3 \\
\hline & & Cohort $(N=1)$ & 1 & & \multirow{3}{*}{1} \\
\hline & & $\operatorname{RCT}(N=1)$ & & & \\
\hline & Blood pressure/Hypertension knowledge & Cross-sectional $(N=2)$ & 2 & & \\
\hline \multirow{4}{*}{ Salt } & Low salt diet adherence & Cross-sectional $(N=1)$ & & & 1 \\
\hline & Salt awareness & Cross-sectional $(N=1)$ & 1 & & \multirow{3}{*}{1} \\
\hline & $24 \mathrm{~h}$ urine & Cross-sectional $(N=1)$ & & & \\
\hline & Health literacy sodium restriction & Cross-sectional $(N=1)$ & 1 & & \\
\hline
\end{tabular}

\subsubsection{Health Literacy and Blood Pressure (Blood Pressure Control and Knowledge)}

There are two outcomes in the blood pressure category; blood pressure control and blood pressure/hypertension knowledge. The majority of studies looking at health literacy and blood pressure control found a significant positive association $(p<0.05 ; N=12)$, while four studies reported non-significant associations $[24,30,33,36]$. Patients with high health literacy tend to have better adherence to medication $[26,28,29,32,39]$ since they are more likely to ask medical questions and involved in patient decision-making [38]. However, a study by Willens et al. (2013) [37] reported conflicting findings. Low health literacy (focused on understanding and appraising health literacy domains) patients had better blood pressure control than those with high health literacy. Patients with inadequate health literacy had much more encounters and, at the very least, are more committed to regular health care, as evidenced by the increased frequency of clinic visits. In addition, a cohort study among primary care patients reported that elevated blood pressure was linked to limited health literacy only for those with undiagnosed hypertension, not among those diagnosed [35].

Two studies reported an association between health literacy and blood pressure/ hypertension knowledge [36,41]. One study conducted among hypertensive patients in Singapore reported that higher health literacy resulted in better knowledge of hypertension but not blood pressure control [36], while Suon and Ruaisungnoen (2019) [41] reported that knowledge on hypertension and sodium restriction are strongly related to the level of health literacy on sodium restriction. 
3.5.2. Health Literacy and Salt Intake (Low Salt Diet Adherence, $24 \mathrm{~h}$ Urine, and Health Literacy Sodium on Sodium Restriction)

Three studies explored the association between health literacy and dietary salt intake. The majority of studies found non-significant associations $(p>0.05 ; N=2)$. These include a study using gold standard salt intake measurement, $24 \mathrm{~h}$ urine collection [3], and a study by Hutchison et al. (2014) [42], which measured low salt diet adherence using a low salt oriented questionnaire and found a non-significant association with health literacy. However, one study [41] on sodium restriction health literacy found that literacy skills, as well as knowledge of hypertension and sodium restriction, and health professional communication, were all found to be strongly linked. However, there is little research that looks at the relationship between health literacy and salt intake.

\subsection{Health Literacy Domains}

Out of 20 studies, only five measured all four domains of health literacy according to Sørensen et al. (2012); one's ability to access, understand, appraise and apply health information $[3,24,25,28,32]$. The majority of health literacy tools used in the review did not measure all four domains. The number of studies assessing each domain was as follows; the ability to access $(N=5)$, appraise $(N=9)$, apply $(N=9)$, and followed by understand $(N=15)$. A few tools assessed all four domains of health literacy, namely European Health Literacy Survey Questionnaire (HLS-EU-Q), European Health Literacy Survey Questionnaire 47-item (HLS-EU-Q47), Health Literacy for Iranian Adults (HELIA), and a tool adopted from Ishikawa et al. (2008) [16] assessing the functional, communicative, and critical skills of the participants.

\section{Discussion}

The causes of poor hypertension management are multifaceted, which include obesity [43], medication adherence [44], dietary and other lifestyle factors [45]. However, from this review, it appears that an individual's health literacy is one of the contributing factors to uncontrolled hypertension. This systematic review identified 20 studies investigating the associations between health literacy with blood pressure control and salt intake. Health literate patients have better hypertension control, [25-29,31,32,35,39,40,46] and knowledge of hypertension [30,36] and sodium restriction [41,47]. However, there were limited and conflicting findings when it came to health literacy and salt intake, and making comparisons between studies difficult due to the different timing and assessment tools.

Although health literacy research has improved over the last decade, before 2012, there was no consensus on the definition or its conceptual dimensions, restricting measurement and comparison possibilities. In addition, there were 16 types of health literacy tools used in the included studies, with only five studies assessing the main four domains of health literacy $[3,24,25,28,32]$ despite the studies being rated as good quality. Most studies assessed the ability to understand health information, with the least focusing on the domains of access, followed by appraise and apply. Access refers to the ability to seek, find, and obtain health information. For example, people with low health literacy tend to postpone or avoid necessary treatment or report difficulty finding a practitioner [46]. Furthermore, health education was less likely to be paid attention to by those with low literacy skills and, as a result, were less likely to manage their disease, according to a systematic study [17].

People may now access a wide range of medical information through smartphones. More significantly, regardless of the skills, anyone may now develop health information and make it available to others [47] which many citizens or patients may find overwhelming when they have to apply or make a well-informed decision about their medical treatment. They may even be at risk of making a judgment that is harmful to their health in extreme circumstances [48]. Furthermore, previous studies have shown that many individuals believe that sodium content on food labels is difficult to read, understand, and interpret or comprehend $[41,49]$. Most instruments used in health literacy research assessed functional 
health literacy skills, which refers to one's ability to locate, read and understand health information [50]. There are only a few measured information appraisals, which are the ability to interpret, filter, judge, and analyze accessed health information, despite widespread agreement that it is a basic set of skills to acquire in today's society [51].

These domains highlight the differences between health literacy and the well-known KAP studies that assessed the respondents' knowledge, attitude, and practice. In comparison with health literacy, KAP does not assess the extent of health literacy which dives into the aspect of one's ability to access, understand, appraise and apply health-related information in healthcare, disease prevention, and health promotion, which has been proven to be a critical health determinant and may have been overlooked until recent years. Therefore, limited studies using appropriate health literacy tools that include the leading four domains highlight the need for more research utilizing the domains in the future.

In terms of blood pressure control outcomes, higher health literacy patients have better control of hypertension, according to most research, and vice versa. However, these findings were inconsistent with a study done in three primary clinics in Nashville with approximately 23,483 hypertensive patients, where it appeared that patients with higher literacy tend to have higher systolic and diastolic blood pressure. Patients with lower health literacy, they claimed, were at least are more inclined to seek regular treatment than those with adequate health literacy, as seen by the higher frequency of clinic visits. However, because these factors may reduce the impact of health literacy, a sensitivity analysis was carried out to adjust the number of clinic visits, and the outcome was unaffected [37]. Surprisingly, a cohort study by McNaughton et al. (2014) [34] reported that low health literacy was only linked to those undiagnosed with hypertension, and most of the existing evidence concerns hypertensive patients. These findings raise concerns that low health literacy may contribute to the high prevalence of uncontrolled blood pressure and being linked to undetected hypertension. More studies looking at these aspects are required among the general healthy population.

There appears to be a lack of studies exploring the link between health literacy and salt intake currently. Therefore, more investigation is required to justify the associations. The current findings on the association are inconsistent [3,41,42]. Out of all salt-related outcomes from studies included, two were shown to be strongly associated with health literacy: salt awareness [3] and health literacy sodium restriction [41]; however, relationships between health literacy and $24 \mathrm{~h}$ urine [3] and low-salt diet adherence [42] were found to be insignificant. Furthermore, several tools used to quantify salt intake may not be robust enough to represent salt intake among the population. Salt intake estimates based on dietary surveys or recall are unreliable [52]. Considering approximately $90 \%$ of sodium intake is eliminated in the urine, $24 \mathrm{~h}$ urine collection is the "gold standard" method for determining salt intake. [53-55]. However, the procedure is difficult for researchers to implement and participants to follow, making $24 \mathrm{~h}$ urine collection impracticable in many cases [53]. In this systematic review, there is only one study where the salt intake was measured using $24 \mathrm{~h}$ urine collection among the workplace community in Switzerland [3]. There was no significant link between health literacy index and salt intake. However, the sample size was constrained because of the organizations' low response rate, which may have influenced the result. This finding is consistent with Hutchison et al. (2014) [42], where a low salt diet-oriented questionnaire was utilized.

Interestingly, individuals with adequate health literacy had a $6 \%$ higher chance of adhering to the low salt diet (OR $=1.06,95 \%$ CI: $0.36-3.10$ ) than those with limited health literacy, but the results remained non-significant. Otherwise, literacy skills were found significantly associated with health literacy sodium restriction. However, because the survey was more health literacy oriented, the tool utilized may not be powerful enough to reflect one's salt intake. Based on current evidence, it has shown promising findings that health literacy could potentially be associated with understanding salt intake but not actual sodium intake that requires a robust tool to evaluate it appropriately, such as from urinary excretion or habitual dietary intake. It is important to highlight that the significant 
factor in the raised blood pressure is a high salt intake, which is accountable for CVD such as strokes and heart attacks [56]. The strong association between hypertension and dietary sodium has been widely recognized in several studies. [57-59].

This systematic review also discussed the relationship between health literacy and hypertension or hypertension knowledge. Health illiterate individuals are likely to have poor hypertension knowledge. Hypertension knowledge and health literacy were found to be significantly linked according to two studies in the review [36,41]. Ko et al. (2013) [36] reported that hypertension knowledge scores were significantly associated with health literacy level. Similarly, a cross-sectional study among hypertensive patients in Cambodia reported that when knowledge of hypertension and sodium restriction improved by one point, the health literacy score increased by 0.266 [41]. This finding demonstrated a link between these two parameters. Previous studies have found that persons who have enough knowledge about their health and salt intake are more inclined to minimize their salt intake for health reasons $[60,61]$. Patients with higher health literacy, according to many researchers, have more knowledge [62,63]; this may be due to the fact that health literacy skills express one's ability to access and understand health information $[64,65]$. Furthermore, to understand printed education materials, patients would need to have higher health literacy. Even if patients with low health literacy could follow the instructions with the picture, they may have a problem communicating with healthcare professionals [66].

The collective evaluation revealed some noteworthy gaps in this area of research, including more research, which is needed to better understand the relationship between health literacy and salt intake, scarcity of evidence among the general population, and appropriate health literacy tools that assess all the crucial domains of health literacy.

\section{Strengths and Limitations}

To the best of our knowledge, our study is the first of its kind to have systematically reviewed and discussed the lack of utilization towards the main domains of health literacy. Furthermore, existing evidence and gaps were identified, and aside from quality assessment, to reduce the risk of bias, the review included grey literature.

Our review also has some limitations. The scope is limited by the available evidence in the literature. Most studies included were cross-sectional, which limits the ability to identify the causal relationship. Cohort or intervention studies should be taken into consideration in the future to produce more valuable findings. In addition, the majority of studies were done among hypertensive individuals. Studies on the general population's health literacy are still limited. There were only a few studies conducted investigating the associations between health literacy and salt intake. The variation of tools and methods used to interpret the results and outcomes were some of the limitations during the review process. These variations rendered comparison across studies difficult.

\section{Conclusions}

It appears that the majority of hypertensive individuals with higher health literacy tend to have better blood pressure control. However, the evidence of health literacy on salt intake itself is still scarce. Future research is needed to assess the applicability of health literacy with salt intake and blood pressure in other resource-limited settings.

Author Contributions: Conceptualization, H.A.M. and D.M.I.; methodology, D.M.I.; analysis, D.M.I.; writing-original draft preparation, D.M.I.; writing—review and editing, D.M.I., S.S., F.J.H., and H.A.M.; supervision, H.A.M. All authors have read and agreed to the published version of the manuscript.

Funding: This systematic review is supported as part of the Newton Fund Impact Scheme and by the Malaysia Industry-Government Group for High Technology (MIGHT). Project funding numbers are IF045-2020 and NN-2020-082. 
Institutional Review Board Statement: This study obtained ethical approval from the Universiti Kebangsaan Malaysia Medical Research Ethics Committee (UKM PPI/1118/JEP-2020-524) National Medical Research Ethics Committee, and others including the international committee.

Informed Consent Statement: Not applicable.

Data Availability Statement: Data is contained within the article or supplementary materials.

Acknowledgments: The authors would like to thank Tan Sing Ean (Department of Social and Preventive Medicine, Faculty of Medicine, University of Malaya, Malaysia) for her valuable cooperation and support during data extraction and analysis. Following application and acceptance, the data mentioned in the publication will be made available upon request.

Conflicts of Interest: F.J.H. is an unpaid member of Action on Salt, Action on Sugar, and its international branch Word Action on Salt, Sugar, and Health (WASSH). The other authors state that they have no competing interests. The funders had no involvement in the study's design, data collection, analysis, or interpretation, manuscript writing, or the decision to publish the findings.

\section{References}

1. Benziger, C.P.; Roth, G.A.; Moran, A.E. The Global Burden of Disease Study and the Preventable Burden of NCD. Glob. Heart 2016, 11, 393-397. [CrossRef]

2. World Health Organization. Cardiovascular Diseases. Available online: https://www.who.int/health-topics/cardiovasculardiseases\#tab=tab_1 (accessed on 15 November 2021).

3. Luta, X.; Hayoz, S.; Gréa Krause, C.; Sommerhalder, K.; Roos, E.; Strazzullo, P.; Beer-Borst, S. The Relationship of Health/Food Literacy and Salt Awareness to Daily Sodium and Potassium Intake among a Workplace Population in Switzerland. Nutr. Metab. Cardiovasc. Dis. 2018, 28, 270-277. [CrossRef] [PubMed]

4. Kearney, P.M.; Whelton, M.; Reynolds, K.; Muntner, P.; Whelton, P.K.; He, J. Global Burden of Hypertension: Analysis of Worldwide Data. Lancet 2005, 365, 217-223. [CrossRef]

5. Department of Statistics Malaysia. Statistics on Causes of Death, Malaysia, 2020. Available online: https://www.dosm.gov.my/ v1/index.php? $r=$ column / cthemeByCat\&cat=401\&bul_id=QTU5T0dKQ1g4MHYxd3ZpMzhEMzdRdz09\&menu_id=L0pheU4 3NWJwRWVSZklWdzQ4TlhUUT09 (accessed on 13 September 2021).

6. Institute for Public Health 2020. National Health and Morbidity Survey (NHMS) 2019: Non-communicable Diseases, Healthcare Demand, and Health Literacy_Key Findings. Available online: https:/ /iptk.moh.gov.my/images/technical_report/2020/4 _Infographic_Booklet_NHMS_2019_-_English.pdf (accessed on 15 November 2021).

7. McNicoll, G. World Health Report 2002: Reducing Risks, Promoting Healthy Life. (Short Reviews). Popul. Dev. Rev. 2003, 29, 137-140.

8. Wang, G.; Labarthe, D. The Cost-Effectiveness of Interventions Designed to Reduce Sodium Intake. J. Hypertens. 2011, 29, 1693-1699. [CrossRef]

9. He, F.J.; Tan, M.; Ma, Y.; MacGregor, G.A. Salt Reduction to Prevent Hypertension and Cardiovascular Disease: JACC State-of-theArt Review. J. Am. Coll. Cardiol. 2020, 75, 632-647. [CrossRef]

10. He, F.J.; Pombo-Rodrigues, S.; MacGregor, G.A. Salt Reduction in England from 2003 to 2011: Its Relationship to Blood Pressure, Stroke and Ischaemic Heart Disease Mortality. BMJ Open 2014, 4, 004549. [CrossRef] [PubMed]

11. Santos, J.A.; Tekle, D.; Rosewarne, E.; Flexner, N.; Cobb, L.; Al-Jawaldeh, A.; Kim, W.J.; Breda, J.; Whiting, S.; Campbell, N.; et al. A Systematic Review of Salt Reduction Initiatives around the World: A Midterm Evaluation of Progress towards the 2025 Global Non-Communicable Diseases Salt Reduction Target. Adv. Nutr. 2021, 12, 1768-1780. [CrossRef]

12. Trieu, K.; Neal, B.; Hawkes, C.; Dunford, E.; Campbell, N.; Rodriguez-Fernandez, R.; Legetic, B.; McLaren, L.; Barberio, A.; Webster, J. Salt Reduction Initiatives around the World-A Systematic Review of Progress towards the Global Target. PLoS ONE 2015, 10, 0130247. [CrossRef] [PubMed]

13. Brown, M.K.; Shahar, S.; You, Y.X.; Michael, V.; Majid, H.A.; Manaf, Z.A.; Haron, H.; Sukiman, N.S.; Chia, Y.C.; He, F.J.; et al. Developing a Policy to Reduce the Salt Content of Food Consumed Outside the Home in Malaysia: Protocol of a Qualitative Study. BMJ Open 2021, 11, e044628. [CrossRef]

14. Sørensen, K.; Van Den Broucke, S.; Fullam, J.; Doyle, G.; Pelikan, J.; Slonska, Z.; Brand, H. Health Literacy and Public Health: A Systematic Review and Integration of Definitions and Models. BMC Genom. 2003, 4, 1-13. [CrossRef] [PubMed]

15. Nutbeam, D. Health Literacy as a Public Health Goal: A Challenge for Contemporary Health Education and Communication Strategies into the 21st Century. Health Promot. Int. 2000, 15, 259-267. [CrossRef]

16. Ishikawa, H.; Yano, E. Patient Health Literacy and Participation in the Health-Care Process. Health Expect. 2008, 11, 113-122. [CrossRef] [PubMed]

17. Sheridan, S.L.; Halpern, D.J.; Viera, A.J.; Berkman, N.D.; Donahue, K.E.; Crotty, K. Interventions for Individuals with Low Health Literacy: A Systematic Review. J. Health Commun. 2011, 16, 30-54. [CrossRef] [PubMed]

18. Peerson, A.; Saunders, M. Health Literacy Revisited: What Do We Mean and Why Does It Matter? Health Promot. Int. 2009, 24, 285-296. [CrossRef] 
19. Pleasant, A. Advancing Health Literacy Measurement: A Pathway to Better Health and Health System Performance. J. Health Commun. 2014, 19, 1481-1496. [CrossRef]

20. Du, S.; Zhou, Y.; Fu, C.; Wang, Y.; Du, X.; Xie, R. Health Literacy and Health Outcomes in Hypertension: An Integrative Review. Int. J. Nurs. Sci. 2018, 5, 301-309. [CrossRef]

21. Pleasant, A.; Cabe, J.; Patel, K.; Cosenza, J.; Carmona, R. Health Literacy Research and Practice: A Needed Paradigm Shift. Health Commun. 2015, 30, 1176-1180. [CrossRef] [PubMed]

22. Halladay, J.R.; Donahue, K.E.; Cené, C.W.; Li, Q.; Cummings, D.M.; Hinderliter, A.L.; Miller, C.L.; Garcia, B.A.; Little, E.; Rachide, M.; et al. The Association of Health Literacy and Blood Pressure Reduction in a Cohort of Patients with Hypertension: The Heart Healthy Lenoir Trial. Patient Educ. Couns. 2017, 100, 542-549. [CrossRef]

23. Shi, D.; Li, J.; Wang, Y.; Wang, S.; Liu, K.; Shi, R.; Zhang, Q.; Chen, X. Association between Health Literacy and Hypertension Management in a Chinese Community: A Retrospective Cohort Study. Intern. Emerg. Med. 2017, 12, 765-776. [CrossRef]

24. Delavar, F.; Pashaeypoor, S.; Negarandeh, R. The Effects of Self-Management Education Tailored to Health Literacy on Medication Adherence and Blood Pressure Control among Elderly People with Primary Hypertension: A Randomized Controlled Trial. Patient Educ. Couns. 2020, 103, 336-342. [CrossRef]

25. Gaffari-Fam, S.; Babazadeh, T.; Oliaei, S.; Behboodi, L.; Daemi, A. Adherence to a Health Literacy and Healthy Lifestyle with Improved Blood Pressure Control in Iran. Patient Prefer. Adherence 2020, 14, 499-506. [CrossRef] [PubMed]

26. Santos Costa, V.R.; Rezende Costa, P.D.; Nakano, E.Y.; Apolinario, D.; Cruz Santana, A.N. Functional Health Literacy in Hypertensive Elders at Primary Health Care. Rev. Bras. Enferm. 2019, 72, 266-273. [CrossRef] [PubMed]

27. Borges, F.M.; Silva, A.R.; Lima, L.H.; Almeida, P.C.; Vieira, N.F.; Machado, A.L. Health Literacy of Adults with and without Arterial Hypertension. Rev. Bras. Enferm. 2019, 72, 646-653. [CrossRef] [PubMed]

28. Selcuk, K.T.; Mercan, Y.; Aydin, T.; Selçuk, K.T.; Mercan, Y.; Aydın, T. Uncontrolled Blood Pressure in Patients with Hypertension and Associated Factors: The Role of Low Health Literacy. Erciyes Med. J. 2018, 40, 222-227. [CrossRef]

29. Hu, K.; Wu, S.; Sun, K.; Zhang, X.; He, C.; Zhao, Y.; Li, Z.; Sun, X. Health Literacy and Its Association with Medication Adherence and Blood Pressure Control among Patients with Hypertension. J. Am. Coll. Cardiol. 2017, 70, C85. [CrossRef]

30. Yilmazel, G.; Çetinkaya, F. Relation between Health Literacy Levels, Hypertension Awareness and Control among PrimarySecondary School Teachers in Turkey. AIMS Public Health 2017, 4, 314-325. [CrossRef]

31. Hall, E.; Lee, S.-Y.; Clark, P.C.; Perilla, J. Social Ecology of Adherence to Hypertension Treatment in Latino Migrant and Seasonal Farmworkers. J. Transcult. Nurs. 2016, 27, 33-41. [CrossRef]

32. Termsirikulchai, L.; Wannasirikul, P.; Sujirarat, D.; Benjakul, S.; Tanasugarn, C. Medication Adherence Of Hypertensive Older Adults Health Literacy, Medication Adherence, and Blood Pressure Level Among Hypertensive Older Adults Treated at Primary Health Care Centers. Southeast Asian J. Trop. Med. 2016, 47, 109.

33. Glashen, M.R. Health Literacy and Hypertension Levels in Urban Latinos; Walden University: Ann Arbor, MI, USA, 2015.

34. McNaughton, C.D.; Kripalani, S.; Cawthon, C.; Mion, L.C.; Wallston, K.A.; Roumie, C.L. Association of Health Literacy with Elevated Blood Pressure a Cohort Study of Hospitalized Patients. Med. Care 2014, 52, 346-353. [CrossRef]

35. McNaughton, C.D.; Jacobson, T.A.; Kripalani, S. Low Literacy Is Associated with Uncontrolled Blood Pressure in Primary Care Patients with Hypertension and Heart Disease. Patient Educ. Couns. 2014, 96, 165-170. [CrossRef]

36. Ko, Y.; Balasubramanian, T.D.; Wong, L.; Tan, M.L.; Lee, E.; Tang, W.E.; Chan, S.C.; Tan, A.S.L.; Toh, M.P.H.S. Health Literacy and Its Association with Disease Knowledge and Control in Patients with Hypertension in Singapore. Int. J. Cardiol. 2013, 168, e116-e117. [CrossRef]

37. Willens, D.E.; Kripalani, S.; Schildcrout, J.S.; Cawthon, C.; Wallston, K.; Mion, L.C.; Davis, C.; Danciu, I.; Rothman, R.L.; Roumie, C.L. Association of Brief Health Literacy Screening and Blood Pressure in Primary Care. J. Health Commun. 2013, 18, 129-142. [CrossRef]

38. Aboumatar, H.J.; Carson, K.A.; Beach, M.C.; Roter, D.L.; Cooper, L.A. The Impact of Health Literacy on Desire for Participation in Healthcare, Medical Visit Communication, and Patient Reported Outcomes among Patients with Hypertension. J. Gen. Intern. Med. 2013, 28, 1469-1476. [CrossRef] [PubMed]

39. Lenahan, J.L.; McCarthy, D.M.; Davis, T.C.; Curtis, L.M.; Serper, M.; Wolf, M.S. A Drug by Any Other Name: Patients' Ability to Identify Medication Regimens and Its Association with Adherence and Health Outcomes. J. Health Commun. 2013, 18, 31-39. [CrossRef]

40. Shibuya, A.; Inoue, R.; Ohkubo, T.; Takeda, Y.; Teshima, T.; Imai, Y.; Kondo, Y. The Relation between Health Literacy, Hypertension Knowledge, and Blood Pressure among Middle-Aged Japanese Adults. Blood Press. Monit. 2011, 16, 224-230. [CrossRef] [PubMed]

41. Suon, M.; Ruaisungnoen, W. Health Literacy on Sodium Restriction and Associated Factors among Patients with Hypertension in Phnom Penh, Cambodia. Nurs. Sci. J. Thail. 2019, 37, 32-41.

42. Hutchison, J.; Warren-Findlow, J.; Dulin, M.; System, H.; Tapp, H.; Kuhn, L. The Association between Health Literacy and Diet Adherence among Primary Care Patients with Hypertension. J. Health Disparities Res. Pract. 2014, 7, 7.

43. Jiang, S.Z.; Lu, W.; Zong, X.F.; Ruan, H.Y.; Liu, Y. Obesity and Hypertension. Exp. Ther. Med. 2016, 12, 2395. [CrossRef]

44. Poulter, N.R.; Borghi, C.; Parati, G.; Pathak, A.; Toli, D.; Williams, B.; Schmieder, R.E. Medication Adherence in Hypertension. J. Hypertens. 2020, 38, 579-587. [CrossRef]

45. Beilin, L.J. Lifestyle and Hypertension-an Overview. Clin. Exp. Hypertens. 1999, 21, 749-762. [CrossRef] [PubMed]

46. Levy, H.; Janke, A. Health Literacy and Access to Care. J. Health Commun. 2016, 21, 43-50. [CrossRef] 
47. Amann, J.; Rubinelli, S.; Kreps, G.L. Revisiting the Concept of Health Literacy. The Patient as Information Seeker and Provider. Eur. J. Health Psychol. 2015, 17, 286-290.

48. Cline, R.J.; Haynes, K.M. Consumer Health Information Seeking on the Internet: The State of the Art. Health Educ. Res. 2001, 16, 671-692. [CrossRef]

49. Temple, N.J.; Fraser, J. Food Labels: A Critical Assessment. Nutrition 2014, 30, 257-260. [CrossRef]

50. Aldoory, L. The Status of Health Literacy Research in Health Communication and Opportunities for Future Scholarship. Health Commun. 2017, 32, 211-218. [CrossRef]

51. Diviani, N. On the Centrality of Information Appraisal in Health Literacy Research. HLRP Health Lit. Res. Pract. 2019, 3, e21-e24. [CrossRef]

52. McLean, R.M. Measuring Population Sodium Intake: A Review of Methods. Nutrients 2014, 6, 4651-4662. [CrossRef] [PubMed]

53. Wielgosz, A.; Robinson, C.; Mao, Y.; Jiang, Y.; Campbell, N.R.; Muthuri, S.; Morrison, H. The Impact of Using Different Methods to Assess Completeness of 24-Hour Urine Collection on Estimating Dietary Sodium. J. Clin. Hypertens. 2016, 18, 581-584. [CrossRef]

54. Land, M.A.; Webster, J.; Christoforou, A.; Praveen, D.; Jeffrey, P.; Chalmers, J.; Smith, W.; Woodward, M.; Barzi, F.; Nowson, C.; et al. Salt Intake Assessed by $24 \mathrm{~h}$ Urinary Sodium Excretion in a Random and Opportunistic Sample in Australia. BMJ Open 2014, 4, 003720. [CrossRef] [PubMed]

55. Van Dam, R.M.; Hunter, D. Biochemical Indicators of Dietary Intake. Nutr. Epidemiol. 2012, 3, 150-154. [CrossRef]

56. Public Health Guideline. Overview I Cardiovascular Disease Prevention Guidance. Available online: https://www.nice.org.uk/ guidance/ph25 (accessed on 28 December 2020).

57. Denton, D.; Weisinger, R.; Mundy, N.I.; Wickings, E.J.; Dixson, A.; Moisson, P.; Pingard, A.M.; Shade, R.; Carey, D.; Ardaillou, R.; et al. The Effect of Increased Salt Intake on Blood Pressure of Chimpanzees. Nat. Med. 1995, 1, 1009-1016. [CrossRef]

58. He, F.J.; MacGregor, G.A. Effect of Modest Salt Reduction on Blood Pressure: A Meta-Analysis of Randomized Trials. Implications for Public Health. J. Hum. Hypertens. 2002, 16, 761-770. [CrossRef]

59. Rose, G.; Stamler, J.; Stamler, R.; Elliott, P.; Marmot, M.; Pyorala, K.; Kesteloot, H.; Joossens, J.; Hansson, L.; Mancia, G.; et al. Intersalt: An International Study of Electrolyte Excretion and Blood Pressure. Results for 24 Hour Urinary Sodium and Potassium Excretion. Br. Med. J. 1988, 297, 319-328. [CrossRef]

60. Bhattacharya, S.; Thakur, J.S.; Singh, A. Knowledge Attitude, and Practice Regarding Dietary Salt Intake among Urban Slum Population of North India. J. Fam. Med. Prim. Care 2018, 7, 526. [CrossRef] [PubMed]

61. Jessen, N.; Santos, A.; Damasceno, A.; Silva-Matos, C.; Severo, M.; Padrão, P.; Lunet, N. Knowledge and Behaviors Regarding Salt Intake in Mozambique. Eur. J. Clin. Nutr. 2018, 72, 1690-1699. [CrossRef]

62. Ko, Y.J.; Karanicolas, P.J. Hepatic Arterial Infusion Pump Chemotherapy for Colorectal Liver Metastases: An Old Technology in a New Era. Curr. Oncol. 2014, 21, e116-e121. [CrossRef]

63. Osborn, C.Y.; Paasche-Orlow, M.K.; Bailey, S.C.; Wolf, M.S. The Mechanisms Linking Health Literacy to Behavior and Health Status. Am. J. Health Behav. 2011, 35, 118-128. [CrossRef] [PubMed]

64. Gazmararian, J.A.; Williams, M.V.; Peel, J.; Baker, D.W. Health Literacy and Knowledge of Chronic Disease. Patient Educ. Couns. 2003, 51, 267-275. [CrossRef]

65. Williams, M.V.; Baker, D.W.; Parker, R.M.; Nurss, J.R. Relationship of Functional Health Literacy to Patients' Knowledge of Their Chronic Disease: A Study of Patients with Hypertension and Diabetes. Arch. Intern. Med. 1998, 158, 166-172. [CrossRef]

66. White, R.O.; Wolff, K.; Cavanaugh, K.L.; Rothman, R. Addressing Health Literacy and Numeracy to Improve Diabetes Education and Care. Diabetes Spectr. 2010, 23, 238-243. [CrossRef] [PubMed] 